\title{
The Fragmentation of Religious Authority in Provincial Towns in Indonesia: The Case of the MUI (Indonesian Muslim Scholar Council) in Pekanbaru and Pontianak
}

\author{
Imron Rosidi \\ Associate Professor of Sociology, Faculty of Da'wah and Communication, \\ State Islamic University of Sultan Syarif Kasim Riau, Pekanbaru, Indonesia \\ imronrosidi@gmail.com \\ Yasril Yazid \\ Associate Professor of Da'wah, Faculty of Da'wah and Communication, State \\ Islamic University of Sultan Syarif Kasim Riau, Pekanbaru, Indonesia \\ yasril.yazid@uin-suska.ac.id
}

\begin{abstract}
Amril
Professor of Educational Philosophy, Faculty of Education and Teacher's Training, State Islamic University of Sultan Syarif Kasim Riau, Pekanbaru, Indonesia amrilm@uin-suska.ac.id
\end{abstract}

\begin{abstract}
This article discusses the fragmentation of religious authority in Pekanbaru and Pontianak, Indonesia, focusing on the local MU (Indonesian Muslim Scholar Council). Employing qualitative methods, the Mu Pontianak and Pekanbaru experience similar religious authority fragmentation due to the human agency. Members of the MUI Pontianak and Pekanbaru represent Islamic organisations in Indonesia's fight for the religious authority of their Islamic organisations, not for the cohesion of religious authority in the MUI. Because religious authority has the desired will, it is no wonder that outside the MUI Pontianak and Pekanbaru many Muslim figures struggle to preserve it. Individuals challenge the religious authority of the MUI Pontianak and Pekanbaru. Some of them are local Muslim preachers. They strengthen and preserve
\end{abstract}


their religious authority by preaching Islam, thus contributing to the growth of the MUI fragmentation in these two cities.

\section{Keywords}

fragmentation - Muslim societies - Pekanbaru - Pontianak - religious authority

\section{Introduction}

Scholars, when discussing religious authority in Muslim societies, refer to ulama (a Muslim scholar having Islamic knowledge and respected in the Muslim community) or kiyai (a symbol given to a Muslim who generally leads an Islamic boarding school) (for example, Burhanudin and Baedowi 2003; Pringle 2010). Robert Pringle (2010, 132) explains that four pillars support the religious authority possessed by a kiyai; religious knowledge, genealogical relations with previous chaplains, heredity (the father is a chaplain) and managerial ability (managing boarding schools). Later he added a fifth element; kiyai's involvement in the tarekat (Sufi order). The five elements described are the foundation for the formation of religious authority in traditional Muslim societies, especially in rural Javanese communities.

However, religious authority in Muslim societies is by no means monolithic. Zulkifli (2013) explains that religious authority is indeed pluralised. Simply put, in the context of Muslim communities in Indonesia, the plurality of religious authority can be seen from the diversity of religious, social organisations there. Each member of a religious, social organisation tends to recognise and support religious leaders in that organisation. In addition, the rapid development of modernisation and globalisation has influenced the diversification of religious authority in Muslim societies in Indonesia. Savran Billahi and Idris Thaha (2018) explain that the modernisation of education in pesantren (an Islamic boarding school) has encouraged the spread of religious authority in various sources. Before modernisation, authority in the pesantren was still entirely concentrated in the figure of the kiyai. The power of a kiyai strongly influences the development of pesantren. After the pesantren underwent modernisation, the kiyai's authority as a single figure in its development diversified into various individuals or institutions such as waqf (Islamic philanthropy) bodies, foundations, cooperatives and so forth.

The development of religious authority in Muslim societies in Indonesia is increasingly fragmented along with the development of communication and the information media (Turner 2007,120 ). If traditional religious authority is 
interpreted to refer to a kiyai, then it is manifested in various figures in the context of the digital era; one of them being the preacher. James B. Hoesterey $(2008,95)$ described Abdullah Gymnastiar or Aa Gym as a celebrity preacher who obtained religious authority from the Muslim community. The religious authority obtained by Aa Gym is not solely through conventional or traditional methods but also through the tradition of intensive learning in pesantren or having a genealogical relationship with the ulama. Still, he does obtain religious authority through religious propaganda or religious lectures on television. The contents of preaching or lectures delivered are also different from traditional patterns. According to Hoesterey (2008), the contents of Aa Gym's lectures are closer to adab or morals and Sufi psychology based on tazkiyatun nafs (purification of the heart or soul). In addition, he prefers to use the attribute or symbol of $A a$ (brother).

Abdul Shomad has also become popular as a preacher who has religious authority among Muslim communities. Compared to Aa Gym, Abdul Shomad has a more qualified religious, scientific base. His educational background is filled with religious education (madrasa, IAIN or State Institute for Islamic Studies and middle eastern education in Egypt, Morocco and the Sudan). In this context, his middle eastern educational background has contributed positively to his image as a Muslim preacher. In addition, his profession as a Hadith (the Prophet Muhammad's words and actions) lecturer at uIN Suska Riau correlates with his role as a preacher. Abdul Shomad's popularity is influenced by social media (YouTube and Facebook) in spreading his da'wa (prolysitizing) messages. The emergence of these preachers shows that digital media has also influenced the emergence of a new religious authority.

The selection of research sites, namely in Pekanbaru and Pontianak, is based on several considerations. First, choosing Pekanbaru as a research location is because it is a Muslim-majority city with an active Islamic religious tradition. The activeness of Muslim communities in applying Islamic teachings can be seen from the rise of the tradition of wirid (religious studies or lectures) at various levels in society, ranging from universities, schools, RT (household organisations) and government institutions to mosques. These 'wirid' activities are fairly instrumental in forming authoritative figures in Muslim societies. Ustadz Abdul Shomad, before becoming popular nationally, was formed in this wirid tradition. Second, in this city, Islamic religious affiliation is not dominated by a single Muslim group or organization, for instance Nahdlatul Ulama or Muhammadiyah, and known as a strong and quite influential Islamic organisation on a national scale. Instead, hybrid and non-mainstream Islamic organisations such as the IKMI (Indonesian Mosque Association) and MDI (Islamic Da'wah Council) has had quite a dominant influence in Pekanbaru. These two organisations have magnificent buildings 
signifying their financial strength on the one hand and their strength in the number of their human resources.

The choice of the city of Pontianak was based on the reason that, firstly, the town has a Muslim population that is almost balanced with non-Muslim residents. The Chinese are seen in every corner of the city as well as Dayaks. Both of these ethnic groups are mostly non-Muslim. Religious issues that arise are quite different from other regions. Issues of religious tolerance and developing information about relations with non-Muslim communities are fairly dominant. No wonder the FKUB (Forum for Religious Harmony) in this city is vital in building a tolerant religious tradition. Secondly, religious authority in Pontianak is dominated by traditional Islamic groups (Nahdlatul Ulama) and because this group has a weak modern management base, the organisation is built traditionally based on the traditional religious authority personally owned by a kiyai.

Compared to rural Muslim communities, urban Islamic societies in Pekanbaru and Pontianak tend to be heterogeneous, dynamic and often connected to the global world. Pekanbaru is the home for about 631.504 Muslims of a 1.093.416 population based on a 2015 statistical report (Yunus 2015). Muslims in Pontianak are about 412.057 from a 556.811 population (Rachmadhani 2018). Based on the above data, these two towns represent other towns in Indonesia where Muslims are the biggest population. However, the religious practice of Muslims in Pekanbaru is more visible than that in Pontianak. This is because, in Pekanbaru, the dominant ethnic groups are padangese whose culture is identical to Islam. In Pontianak, although Malay is the dominant ethnic group with about 143,348 people, the second dominant ethnic group are Chinese, about 106.897 people (Rachmadhani 2018). The latter are not identified with Islamic culture. Furthermore, Pekanbaru is a relatively homogenous ethnic group, while Pontianak is a multi-ethnic town. This article aims to learn more about these demographic differences that may affect the different religious authority fragmentation paths in these two cities.

These two cities impact on the increasingly widespread religious authority, manifested in figures, social institutions and modern texts. Thus, research related to religious authority in urban Muslim societies in Pekanbaru and Pontianak has become important in explaining the fragmentation of religious authority within the MUI in these two towns. The study of religious authority fragmentation in local towns in Indonesia has not been undertaken much by scholars. Jajat Burhanudin and Ahmad Baedowi (2003) discussed the transformation of religious authority in Indonesia based on a biographical approach. They explained the biographies of 14 (fourteen) Muslim scholars or kiyais who were well known in the national context. One of them is KH. Hasyim Ashari. The study of kiyai figures that are well known nationally 
does not indicate the dynamics of religious authority today that spreads to many institutions and social actors.

In a traditional society, religious authority is still possibly controlled by traditional figures. However, in an urban society, where the development of information through digital media is so rapid, religious authority can manifest itself in various forms, figures and social institutions. Clerics or scholars like $\mathrm{KH}$ Hasyim Ashari have religious authority. Still, the study of the dynamics of religious authority after the emergence of new preachers that are popular in urban society needs to be explained. Zulkifli's study (2013) also explains religious authority and scholars in the macro context of Indonesia. Although the findings are helpful in explaining religious authority as an arena of contestation for Islamic groups, his writing has not elaborated much in detail. Another study is "Varieties of Religious Authority: Changes and Challenges in 2oth Century Indonesia", edited by Azra, Dijk, and Kaptein (2010). This study explains the diversity of religious authorities in Muslim societies in the 2oth century. The articles in this book are, therefore, likely to use an historical approach.

In Indonesia, religious authority is formally represented by Ulama (Muslim scholars) organisations called the MUI (Majelis Ulama Indonesia or Indonesian Muslim Scholar Council). The central MUI in Jakarta has several branches in provincial towns in Indonesia. The development of the MUI in the local context is interesting to study related to the dynamics of the religious authority fragmentation described above. The notion of religious authority fragmentation refers to the plurality of th MUI members representing their Islamic organisations. Every member of the MUI in Pekanbaru and Pontianak has represented his own organisation so that he does not put the MUI as his main organisation. This has caused conflict among actors in the MUI, resulting in the fragmentation of the local MUI in Pekanbaru and Pontianak. This indicates that the MUI is basically not monolithic. It has been fought over based on the different motivations of these actors in the MUI.

\section{$2 \quad$ Methodology}

The analytical method of this article is based on Anthony Gidden's concept of human agency and structure. According to him, as quoted by Keskin $(2011,1)$, "every structure (such as Islam) has human agency". In this case, the MUI as a social structure actually has human agency. The MUI has some rules and regulations, but it cannot be run without the role of Muslims as its members. Furthermore, Bayat (2011, 6-7) argues that Muslims have the agency to define 
Islam. As a result, a Muslim or a group of Muslims in the MUI may have different definitions and interpretations about how to be a true Muslim though they are referring to the same text. In the Indonesian context, the role of authoritative people is substantial in defining and interpreting the scriptural texts because their native languages are not Arabic as in the texts. This creates multiple definitions and interpretations of the texts because " the Qur'anic text is mute, most will accept that for it to become relevant to their lives, it requires interpretation, highlighting the issue of religious authority" (Kramer and Schmidtke 2006, 4).

Based on the above concept, this article argues that the fragmentation of religious authority is actually inherent within the MUI in Pekanbaru and Pontianak. In these organisations, multiple ideas and interpretations proposed by Muslims regarding Islam and other issues are contested and negotiated. In principle, both the MUI in Pekanbaru and Pontianak accommodate representatives from diverse Muslim organisations to be their members. The goal of this accommodation is actually to unify the diversity of Muslim organisations. However, such heterogeneity also causes fragmentation within the MUI in Pekanbaru and Pontianak. Every Islamic organisation that sends its representatives to be members of the MUI in Pekanbaru and Pontianak has certain ideologies. Muhammadiyah and Nadlatul Ulama, for instance, are two Islamic organizations having representatives in the MUI Pekanbaru and Pontianak. They actually have different ideologies. Muhammadiyah is a reformist Islamic organisation, while Nahdlatul Ulama is "primarily an organisation of Traditionalist clerics or Kiai” (Pringle 2010, 116).

This study uses descriptive qualitative methods. Northcott $(2016,294)$ explains that qualitative methods rely on participant observation and in-depth interviews. This study focuses on the local MUI (Islamic Muslim Scholar Council) members in Pekanbaru and Pontianak. In-depth interviews were conducted with Muslim figures in the MUI in Pekanbaru and Pontianak to find out more about the fragmentation of religious authority in this organisation. There were twelve people interviewed. Six people are Muslim figures in Pekanbaru and the rest are Muslims in Pontianak. The observations were conducted in the permanent and temporary offices of the local MUI Pekanbaru and Pontianak. The questions proposed during the interview were related to the religious fragmentation within the MUI, such as its members coming from multiple Islamic organisations, its relation with the local state, etc. In order to protect their privacy as desired this article uses a pseudonym. This article proposes some questions: how is the fragmentation of religious authority represented in the MUI of these two towns? Is there any different religious fragmentation in the local MUI of these towns? If yes, what are these differences? 
Data collected has been analysed based on Gidden's concept of structure and human agency. Based on Gidden's concept, this article argues that the term 'structure' refers to the MUI Pontianak and Pekanbaru. In contrast, the term 'human agency' refers to the MUI Pontianak and Pekanbaru members. In analysing the research findings, this study allowed the collected data to support this concept. In this context, Gidden's concept of structure and human agency is developed through careful empirical observations. Based on this specific proposition, this study follows the informants' narratives, which have become the basis for the discussion and conclusion.

According to Kaptein $(2004,115)$, religious authority is a broad concept that can manifest itself in religious forms: in texts, individuals, groups or groups of people and social institutions. Meanwhile, according to Max Weber, as quoted by Zulkifli (2013), authority consists of three categories: charisma, rationale and traditional authority. Religious authority can, in essence, be categorised into charisma and traditional authority. This is because the authority possessed by social actors or institutions is based on capabilities that represent "a set of norms, procedures, and traditions to be implemented in a social unit" (Weber 1957, 329). The spread of religious authority has combined in figures and in the form of texts and media. In history, no single social actor or media has been able to bind Indonesian Muslim communities into a single monolithic group. In addition, in a digital era such as today, religious authority can manifest itself in various forms, for example, in the form of texts distributed by digital media through websites, Facebook, Whatsapp, etc. Muslims can easily seek answers to the religious problems they face by accessing digital media. Through websites written by a number of people, Internet media provide practical answers in terms of figh (Islamic law), theology and so forth. Most Muslims then use this religious virtual space as a source of new religious authority to solve the religious problems they face.

Due to its broad concept, in this study, the concept of religious authority is limited to the groups of people represented in the MUI (Majelis Ulama Indonesia or Indonesian Islamic Scholar Council). The MUI is a semi-governmental organisation that can be called an association of religious authorities recognised on a national scale. This is partly triggered by the term ulama, which is embedded as a name in the organisation. The term ulama, according to Norshahril Saat (2012), means "people of knowledge" and is mentioned twice in the Qur'an. Thus, the ulama is a term that refers to a respected social group 
because it is often mentioned as "waratsatul Anbiya", the religious authority in Indonesia since the New Order was formally manifested in the MUI. The diversity of religious authority in Indonesia has tried to become unified in this organisation, which was established during the New Order in 1975. The establishment of the MUI in this context cannot be separated from the political motives of the government. It tried to control Muslim scholars (ulama) so that they supported its policy (Bowen 1999, 93). In this context, the New Order regime understood the diversity of religious authority in Indonesia. The new order then provided the MUI as an organisational umbrella for this diversity to control the fragmentation of religious authority. The New Order under Soeharto's presidency propagated the importance of unity for development programs. The establishment of this organisation reflected this government spirit. Ichwan and Noor (2019) gave examples of the use of the MUI as the government's vehicle to disseminate its agenda packed in religious idioms. Some government programs such as family planning (Keluarga Berencana), transmigration and the Pancasila acceptance were supported by the MUI through its religious order called a fatwa. However, since the collapse of the New Order, the MUI has started to keep a distance from the state. This is intended to improve its image as the Muslim community servant, not a state servant as the New Order period.

Because it attempts at keeping a distance from the state, the MUI also faces complicated religious authority fragmentation internally. When it is closer to the state, any differences may still be controlled by the state. However, when it is closer to Muslim communities, the MUI should accommodate multiple understandings as well as the diversity of religious authority of Muslim societies within this organisation. Furthermore, it is actually difficult for the MUI to keep a distance from the state since infrastructures and financial issues have been supported by the state. Its central building in Jakarta is still located on government land. Every year, the state provides a specific financial budget for the MUI. In fact, in these two towns (Pekanbaru and Pontianak), local government support is desired by the local MUI. This shapes the fragmentation of the MUI as the religious authority holder.

\section{Religious Authority in Pontianak}

Pontianak is a unique city in terms of diversity. On the one hand, Islam has more adherents but its visibility in the public sphere is not dominant. Other religions such as Buddhism and Confucianism are visible in the public sphere. This can be seen from their places of worship which demonstrate 
their visibility balancing Islamic symbols in public life. The Islamic religious landscape of this city is not as visible as might be found in a number of other cities in Indonesia. Pontianak is located in the western part of the island of Kalimantan. Muslim communities in Pontianak tend to be more intensive in making social contact with non-Muslims. This is at least evident from the practice of buying and selling and other activities in everyday life. Although the Muslim community is still more than the non-Muslim community in quantity, issues of interaction with non-Muslim communities dominate questions from the Muslim community to religious authority holders in Pontianak.

The MUI in Pontianak is not very active in shaping the development of religious authority. It is influenced by the diversity of its members, especially in terms of organisational background. Every member of the MUI in Pontianak represents a certain Islamic organisation in Pontianak. The MUI Pontianak is then, as a 'structure', negotiated by its members. As an active agent, each member of the MUI in Pontianak has different religious understandings, which cause its organisation management problems. There are only two active members in the MUI Pontianak. Even during the fieldwork, the head of the MUI, Pontianak was not present due to his personal activities. An active member of the MUI Pontianak (Busro, e-mail message to author, July 24, 2018) ${ }^{1}$ explains:

"I joined the MUI more than ten years ago...this organisation accommodates many Muslims from different Islamic organisations. They have different personal activities outside the MUI. Maybe they are busy in their Islamic organisations, I don't know...actually, we try to get financial support from the local government to improve our organisation structure, organisation activities and so on. We have even proposed to local government to be given a building as the MUI office. But, we always fail."

The above statement indicates that the MUI Pontianak has multiple backgrounds for its members. Due to this diversity, not every person within the MUI Pontianak focuses on the development of the organisation. Some of them blame the local government because it does not support the existence of the MUI Pontianak. This indicates that the existence of the MUI Pontianak is troubled by the fact that there is no financial aid from the local government. As active agents, Muslims in the MUI Pontianak need economic support as well as a comfortable place to work. In fact, the MUI Pontianak does not have a permanent office. When the MUI Pontianak conducts a meeting, it is usually done

1 All interviewees' names are pseudonyms. 
in several places, such as in the Pontianak religious affairs ministry office. This means that keeping a distance from the state is difficult to implement in the MUI Pontianak. An active member of the MUI Pontianak (Ahmad, Facebook message to author, July 14, 2018) argues that:

"Local government should consider the important role of the Indonesian Ulama Council (Majelis Ulama Indonesia). It is a representation of religious authority. It must be considered in the context of fostering a mutually beneficial relationship between the religious authorities and the state. The MUI in Pontianak is intentionally given a 'way' by local government to demoralise its organisational structure."

As a respected organisation at the central level, the MUI Pontianak has a kind of 'marwah' (dignity). The state should see it as a worthy organisation being placed in an equal position. In fact, according to Ahmad, the dimension of equality between State and religious authority enables effective collaboration for the Ummah (Islamic society). However, local government financial support for the existence of the MUI is absent. This is due to the fact that Pontianak local government may allocate its financial support to government institutions such as education and religious affairs ministry offices. In fact, the MUI Pontianak is not a government institution. However, financial support from local government is not the only problem faced by the MUI Pontianak.

Another problem of the MUI in Pontianak is related to the obscurity of the term 'representative' in the MUI Pontianak. Because the MUI is an umbrella organisation, it actually accommodates almost all Islamic organisations in Pontianak as its members. These Islamic organisations include Nahdlatul Ulama, Muhammadiyah, FPI (Islamic Defenders Front) and many others. However, some Islamic organisations like Muhammadiyah consider that the MUI Pontianak does not accommodate their members fully to be representatives in the MUI. This is related to how many people of these Islamic organisations sit within the organisational structure of the MUI. A member from the Muhammadiyah Pontianak organisation (Ridwan, e-mail message to author, August 8, 2018) said:

"The MUI Pontianak is recently dominated by a certain organisation, not Muhammadiyah. ...But no problem. For us, our priority is in the social sector, which is not the focus of the MUI."

In fact, the 'certain organisation' stated above refers to a traditional Islamic organisation called Nahdlatul Ulama. The relationship between 
Muhammadiyah and Nahdlatul Ulama is actually in a relationship of 'mutual suspicion' even though it is not acute. This 'unfriendly but friendly' relationship has been seen since the founding of the two organisations in Indonesia. Historically, Nahdlatul Ulama was founded in Yogyakarta by KH. Hasyim Asy'ari motivated by a desire to reject the spirit of renewal of Muhammadiyah, which was considered to 'disturb' the religious traditions of the traditional Muslim community. The issue of representation in the MUI Pontianak is one of a number of issues that illustrate the differences between the two organisations. Muhammadiyah members assumed that the MUI Pontinak tended to accommodate Muslims from Nahdlatul Ulama in its organisational body.

The debate over the feasibility of a figure representing the diversity of Islamic religious organisations in the MUI Pontianak is actually complicated. In the Indonesian context, the face of Islamic organisations is very diverse. Each has a different membership and organisational structure. Every Islamic organisation tends to prioritise its own groups in fighting for its religious organisation's authority in the MUI. The need to fight for the religious authority of these organisations basically causes the fragmentation of religious authority in the MUI internally. The MUI Pontianak basically provides a space for each Islamic organisation in Pontianak to send its figures to be members of the MUI. These figures, however, prefer the sound of the religious authority of their Islamic organisations to the cohesion of the MUI. Furthermore, each Islamic organisation also requires the availability of representative space in the MUI so that they generally provide figures that are considered to represent the organisation in the MUI. When those figures are absent from the MUI, the sense of belonging towards the MUI fades. This is therefore reducing the religious authority of the MUI.

Furthermore, in the Indonesian context, the role of human agency is sometimes more important than the role of structure, such as Islamic organisations. It is unsurprising that, in a social organisation, the movement and progress of the organisation are usually more determined by the role of personal figures within it. An Islamic organisation then manifests the need by choosing a publicly known figure who can become a 'broker' or 'fixer' in the context of moving the wheels of the organisation. As a 'fixer', he must be a central figure who solves financial, facility or other problems. As a 'broker, he must be able to become the patron's client. Patrons in this context are state authorities who contribute material and provide legality for organisational matters.

The MUI Pontianak issue cannot be separated from the absence of prominent figures in the body of this organisation. Without a prominent figure, the MUI Pontianak is unable to move closer to the local state. This is influenced by the character of Indonesian citizenship, which, according to Berenschot 
and Klinken (2019), is highly impersonal. This requires a broker or mediator to interact with the state. Thus, personal figures are needed in the body of the MUI to sustain their movements while fostering relations with State authorities. In this context, it is seen that religious authorities need 'mediators' who liaise with state authorities. This is what is absent at the MUI Pontianak.

Far from the centre of power in Jakarta, Pontianak has a gap or a considerable distance from modernity. The ability to adapt to new developments is a problem in itself. The 'far distance' from the centre of power requires more complicated and challenging interaction with the state. Due to the lack of personal figures who can play a role in mediating religious authority to gain access to State authority, the MUI Pontianak does not have adequate physical space for the benefit of the organisation.

Not surprisingly, this organisation is quite ample in quantity but most are not actively involved in the MUI. In this research, it has been seen that those who are quite active and trying to maintain the religious authority of this organisation are the Chairperson and General Secretary of the MUI. When visited, the General Secretary shyly and frankly revealed that the organisation's condition was experiencing a 'crisis'. Lacking the support of an adequate organisational infrastructure, he told me that he was trying to move the organisation's struggling wheels. Because it focuses on internal organisational improvement, the MUI Pontianak tends to ignore the issue of religious authority in the Muslim communities of Pontianak. This is because it has hierarchically complex organisational problems. Within the MUI Pontianak, the aura of authority as an institution is less visible.

As an organisation facing membership fragmentation, the MUI Pontianak cannot neglect the rise of new religious authority outside the organisation. Although the authority in Pontianak is still not as massive as in cities like Jakarta, its presence is quite visible in the public sphere. The presence of new religious authorities in Pontianak can be seen from the aggressiveness of transnational Islam in strengthening the da'wah (prolysitizing) network through mosques and charitable institutions. This transnational Islamic group can be called an authority that displays aggressive and active religious behaviour. The holder of this new religious authority has some difference from the MUI. They are distinguished in three ways in the methods, instruments and background of the holders. In terms of methods, this transnational Islam tends to be more active in maintaining religious authority. This activity is important in strengthening their function as connectors to the religious traditions of the Prophet PBUH.

In carrying out their religious functions, the holders of this new religious authority directly emphasise the question-and-answer method. This method 
is considered important as one way of clarifying religious issues that are confusing in the midst of urban Muslim society. In addition, the direct question and answer method is an ideal way of strengthening the structure of this new religious authority. In the context of urban society, the direct question and answer method opens Islamic religious spaces to be more dialogical in manner. These new religious authority holders in Pontianak have strong religious responsibilities related to complex contemporary problems. In the context of modernity that continues to grow today, religious issues or problems that are increasingly complex and complicated require exacting and authoritative religious answers. In online media, this method is also applied to support this new religious authority. Through Facebook and YouTube, for instance, someone can be elevated to be authoritative in religious aspects (Burhani 2018, 148-149) because these mediums enable him or her to directly answer religious problems proposed by the users.

In terms of instruments, the new religious authorities tend to be more varied in spreading Islamic religious traditions. They are generally accommodating towards modern instruments or media such as social media and electronics. In addition, these new religious authorities have a hybrid character that accommodates the values of modernity. Their desire to spread Islam in society does not forbid them to receive abundant economic rewards. This shapes the manner of their preaching. They are not reluctant to get profit from their preaching. This new religious authority of transnational Islam also invites some people to be their staff to promote preaching. These staff may come from a non-Islamic educational background (Weng 2018). As a result, this new religious authority relies on Islamic knowledge and other disciplines to disseminate their religious authority.

Furthermore, outside the MUI Pontianak, some Muslim figures challenge the religious authority of the MUI Pontianak. They represent the dynamic landscape of human agency. These Muslim figures are active Muslims having a religious understanding and knowledge of Islam. Their active human agency is affected by their understanding of the social structure (Islam). Some of them are Muslim figures who sit in mainstream Islamic organisations in Pontianak. They generally have strong connections with the local state authority. The local state authority in Pontianak prefers giving financial support to them rather than the MUI Pontianak. This is because the former have many members who may contribute to political support for the local state, while the latter does not. This condition allows these Muslim figures to get access to the local state authority in maintaining and preserving their religious authority and challenging the religious authority of the MUI Pontianak. 
Compared to Pontianak, the MUI Pekanbaru represents a distinctive and unique organisational character. In the MUI Pekanbaru, the human agency represented by some of its members is vital in shaping the development of the MUI in Pekanbaru. No wonder the religious authority of the MUI Pekanbaru resides in individuals (agents) rather than organisations (structures). Its organisation tends to be affected by the religious authority inherent in individuals. This illustrates that the selection of popular, dynamic and authoritative figures is very important in moving the organisational wheels of the MUI Pekanbaru.

Not surprisingly, the structure of religious authority in the MUI Pekanbaru is formed and developed based on the religious authority of individuals. The MUI Pekanbaru tends to be managed personally. Therefore, one figure who sits in the MUI Pekanbaru can be involved in many Islamic organisations. Muslim figures in Pekanbaru who are considered authoritative are needed by Islamic organisations, not only by the MUI, to lead and manage these organisations. Some of them, such as Ahmad, Hamid and Abdullah (none are real names), have important positions in the MUI Pekanbaru and Islamic organisations such as Nahdlatul Ulama, Muhammadiyah, Prosperity of the Indonesian Mosque Management (IKMI), Majelis Dakwah Islamiyah (MDI or Islamic Prolysitizing Council) and F KUB (Forum for Religious Harmony) Pekanbaru.

The impact of this means that the MUI in Pekanbaru has 'quite intimate' connections with the state (local government) authority. They have the power of mediation with State authority. Therefore, local State support for the MUI in Pekanbaru is quite satisfactory compared to the MUI in Pontianak. This makes the abundance of facilities and finance available for the MUI Pekanbaru not comparable to the MUI Pontianak. The MUI Pekanbaru has been provided with a luxurious mosque accompanied by a big office as well as an official car for its main operational work. Hamid is a very busy Muslim figure in Pekanbaru. He has been involved in three Islamic organisations recently. He is a member of the MU I Pekanbaru, F KU в Pekanbaru and I кмı Pekanbaru. He (Hamid, e-mail message to author, August 18, 2021) said:

“ I basically was not asking for this position...I did not know. Maybe because I have a strong connection with some people in local government..."

The MUI in Pekanbaru is thus dependent on the local state authority. This is basically contrary to the central MUI in Jakarta that tries to keep a distance from the state to reach its religious authority independence. The MUI 
Pekanbaru tends to be the local government servant rather than the ummah (Muslim community) servant. However, the MUI Pekanbaru rejects this. Its active member (Said, Facebook message to author, August 25, 2018) argued:

"State and ulama should collaborate... It is for the benefit of the ummah... We cannot be dictated to by local government, I think.."

The intimate relationship between the MuI Pekanbaru and the local state does not mean that there is no religious fragmentation in the MUI Pekanbaru. Its members come from multiple Islamic organisations, so that they are busy with activities outside the MUI Pekanbaru. The MUI Pekanbaru members are mostly active in two dakwah (prolysitizing) organisations, namely the IKMI and MDI. In contrast to NU and Muhammadiyah, which emphasise the identity of organisational religious understanding, IKMI and MDI further emphasise the identity of personal religious understanding. Personal religious understanding naturally contributes to the diversification of religious authority within the MUI Pekanbaru. This is because each figure who is considered authoritative about Islam tries to spread or at least maintain his respective religious understanding. The MUI Pekanbaru members often use the IKMI and MDI as their vehicle to disseminate personal religious authority in Pekanbaru. Every Friday, the IKMI and MDI send them to mosques in Pekanbaru to give religious speeches. They get economic feedback from the mosque but they also get religious authority improvement personally. These two dakwah organisations actually contest the religious authority of the MUI Pekanbaru.

The diversity of local Muslim preachers in Pekanbaru has been growing, challenging the MUI development in Pekanbaru. In this context, the agency of Muslims has a role in shaping the development of the MUI in Pekanbaru. Many of these local preachers prefer to use the symbol 'ustadz' (derived from Arabic and meaning teacher) rather than the kiyai. The use of this new symbol illustrates at least a number of things. Firstly, the religious authority becomes more flexible so that many actors can contest it. The kiyai symbol tends to be tighter because it emphasises the importance of the actor's involvement with traditional education or pesantren. Not surprisingly, preachers, who do not have a background in the pesantren education tradition, are reluctant to use this symbol. Because of their flexibility, many Muslims, in order to obtain religious authority, often use the symbol of 'ustadz'. Secondly, this new symbol (ustadz) also plays a role in encouraging diversified religious authority in such a way. In this context, religious preachers who know nothing new about Islam but have an ability or skill in preaching to the Muslim community can provide this new symbol. This title or symbol shows that the new preacher has 
recognised religious authority so that the contents of his preaching may be heard and followed. These Muslim preachers having the ustadz symbol have been recently dominating the religious authority in Pekanbaru, contesting the religious authority of the MUI Pekanbaru. The MUI in Pekanbaru rarely receives questions related to religious issues from Muslim communities. This is because most of the questions are more focused on conventional religious issues of worship. These issues are sufficiently resolved by religious authority holders who have the closest relationship with the community, like their Ustadz and preachers.

One of the local preachers in Pekanbaru is Irham (not his real name-), who is very active in preaching in several places in Pekanbaru. He does not sit in the MUI Pekanbaru but he is a member of the MDI Pekanbaru. In terms of background, Irham is a lecturer at UIN (the State Islamic University) Pekanbaru. He has a traditional Islamic background closely tied to the Nahdlatul Ulama $\mathrm{NU})$ Islamic organisation. His unbureaucratic religious authority can be seen from his religious authority dissemination. He often receives religious questions from the Muslim community related to many things, for example, halal (permitted)-haram (forbidden) food, the most important (sunnah) prayers and so forth. After receiving these questions, he directly answers in the forum. However, the MUI Pekanbaru has to conduct a meeting with its members to discuss first before giving an answer to a question proposed by a Muslim. This may take several days or weeks because inviting its members to meet needs much time. The discussion can be filled with debates and negotiation representing multiple Islamic organisations and different Islamic interpretations during the meeting.

Other figures in Pekanbaru challenging the religious authority of the MUI Pekanbaru are the 'Gharims' of mosques. The gharims are those in charge of taking care of 'mosques' ranging from cleaning to praying in the congregation. The gharim is usually chosen by the mosque management based on his religious knowledge, not physical strength. At least he must have the ability to read the Qur'an or memorise short chapters in it. This ability is expected to support the gharim when the mosque's 'imam' is unable to do the task so he can replace him. The Gharim of the mosque in Pekanbaru is recognised as playing a vital role in preserving religious traditions on the one hand and forming a fundamental religious authority in the urban Muslim community in Pekanbaru on the other. The gharim generally interacts intimately with mosque worshipers. They sometimes question issues of modernity or daily life, which is then responded to by the gharim. At this point, the ability of the gharim to answer perfectly or authoritatively in matters of Islam may place him in a position that counts in the fragmentation of religious authority in 
the MUI Pekanbaru. And this position has become a challenge for the MUI Pekanbaru since their flexible and unbureaucratic religious authority enables them to preserve and maintain religious authority in Pekanbaru.

Religious authority in Pekanbaru and Pontianak has experienced fragmentation. This fragmentation is not only due to the rise of communication media technology. However, it is mainly because of Muslims themselves as active agents. Every member in the MUI Pekanbaru and Pontianak has the agency to define Islam. The MUI Pekanbaru and Pontianak development as 'structures' is negotiated by its members as active agents. They have multiple understandings of Islam which support the rise of different Islamic streams and ideologies within the MUI in Pekanbaru and Pontianak. In fact, the establishment of the MUI is an attempt to unify these multiple Islamic ideologies. However, as this study has found, the human agency of Muslims contributes to fragmentation within the MUI Pontianak and Pekanbaru.

The MUI in these two cities, however, has a different experience of fragmentation. In Pekanbaru, the state authority supports the development of the MUI Pekanbaru through its financial assistance because some MUI Pekanbaru members can approach the local government. However, in the MUI Pontianak, state authority is absent and unable to support its development because there is no member of the MUI Pontianak who has the ability to approach the local government. Furthermore, due to the human agency of Muslims, some actors are challenging the religious authority of the MUI Pontianak and Pekanbaru. Some of them that can be mentioned here are gharim or mosque caretakers, local Muslim preachers and local mainstream Islamic organisation figures.

Religious authority comes with a desired will, so it is no wonder a number of Muslim figures in the MUI Pontianak and Pekanbaru struggle to preserve it. The strategy taken is certainly not monolithic. Members of the local MUI both in Pontianak and Pekanbaru maintain their religious authority by continuing to persist in these religious organisations. From period to period, they struggle to stay involved in the MUI in a serious effort to maintain religious spirit on the one hand and strengthen their religious authority on the other. These Muslim figures may not get much economic benefit from their continuing involvement in the MUI but they can get religious benefit understood by themselves called pahala (religious rewards). However, certain figures outside the MUI are also struggling to preserve and improve their religious authority challenging the religious authority of the MUI Pontianak and Pekanbaru. 
A number of gharim (mosque's caretakers) in Pekanbaru maintain their religious authority by strengthening their scientific base by studying formally in universities and informally through disseminating knowledge by preaching religion. Local preachers strengthen and preserve their religious authority by continuing to preach Islam (da'wah). They stand or sit in front of their congregation every week to preserve and even strengthen the religious authority they already have. It is important for them to continue preaching Islam to present evidence that the existence of their religious authority is not yet extinct.

However, the MUI Pekanbaru and Pontianak fragmentation can be suspended over some issues like the Palestine war and Islamic blasphemy. Members of the MUI in Pekanbaru and Pontianak united during a large-scale demonstration on December and a few years ago. The event, which is famous for the term 212 actions (Aksi 212), illustrates a particular issue that can unite the fragmentation of religious authority. Thus, certain issues related to Islam enable the cohesion of such fragmented religious authorities temporarily. In these two cities, the cohesion of the MUI will very likely occur if they see the same enemy. The enemies that can be mentioned here are; harassment of Islam, including blasphemy against important figures of religious authority, oppression of Muslims, injustice against Muslims and other general Islamic religious issues. It is unsurprising that these issues are often voiced by the MUI in both cities, Pekanbaru and Pontianak. Their reason is obvious, namely to unite against such religious fragmentation. However, it should be underlined in this article that one issue is still debatable (because it needs further research) and that is the presence of transnational religious authority (such as salafi Islam) that encourages diverse religious authority within the MUI in these two cities to cooperate with one another.

\section{References}

Azra, Azyumardi, Kees van Dijk, and Nico J.G Kaptein. eds. 2010. Varieties of Religious Authority: Changes and Challenges in the 2oth Century Indonesia. Singapore: Institute of Southeast Asian Studies.

Bayat, Asef. 2011. Pos-Islamisme. Translated by Faiz Tajul Milah. Yogyakarta: LKiS.

Berenschot, Ward, and Gerry van Klinken. 2019. "Citizenship in Indonesia: Perjuangan atas Hak, Identitas dan Partisipasi." In Citizenship in Indonesia Perjuangan atas Hak, Identitas dan Partisipasi, edited by Ward Berenschot and Gerry van Klinken, 1-42. Jakarta: KITLV and Yayasan Obor Indonesia.

Billahi, Savran, and Idris Thaha. 2018. Bangkitnya Kelas Menengah Santri: Modernisasi Pondok Pesantren di Indonesia. Jakarta: Prenadamedia Group. 
Bowen, John. R. 1999. "Legal Reasoning and Public Discourse in Indonesian Islam." In New Media in the Muslim World: The Emerging Public Sphere, edited by Dale F. Eickelman and Jon W. Anderson, 80-105. Bloomington: Indiana University Press.

Burhani, Ahmad Najib. 2018. "Plural Islam and Contestation of Religious Authority in Indonesia." In Islam in Southeast Asia: Negotiating modernity, edited by Norshahril Saat, 140-63. Singapore: ISEAS.

Burhanudin, Jajat, and Ahmad Baedowi, eds. 2003. Transformation of Religious Authorities: Indonesian Islamic Experience. Jakarta: PT Gramedia Pustaka.

Hoesterey, James B. 2008. "Marketing Morality: The Rise, Fall and Rebranding of Aa Gym." In Expressing Islam: Religious Life and Politics in Indonesia, edited by Greg Fealy and Sally White, 95-112. Singapore: Institute for Southeast Asian Studies.

Ichwan, Moch. Nur., and Nina Mariani Noor. 2019. "Arah Baru Majelis Ulama Indonesia." In Ulama dan Negara Bangsa: Membaca Masa Depan Islam Politik di Indonesia, edited by Noorhaidi Hasan, 67-96. Yogyakarta: PusPIDeP and Pascasarjana UIN Sunan Kalijaga.

Kaptein, Nico JG. 2004. "The Voice of the Ulama: Fatwas and Religious Authority in Indonesia." Arch. De Sc.soc.des Rel 125: 115-130.

Keskin, Tugrul. 2011. "The Sociology of Islam." In The Socilogy of Islam: Secularism, Economy and Politics, edited by Tugrul Keskin, 1-18. Reading: Ithaca Press.

Kramer, Gudrun, and Sabine Schmidtke. 2006. Speaking for Islam: Religious Authorities in Muslim Societies. Leiden: Brill.

Northcott, Michael S. 2016. "Pendekatan Sosiologis." in Aneka Pendekatan Studi Agama, edited by Peter Connolly, 271-314. Yogyakarta: Ircisod \& L KIS.

Pringle, Robert. 2010. Understanding Islam in Indonesia: Politics and Diversity. Singapore: Editions Didier Millet PTE Ltd.

Rachmadhani, Arnis. 2018. "Dimensi Etnik dalam Kerukunan Umat Beragama di Pontianak Provinsi Kalimantan Barat." Panangkaran 2(1): 1-21.

Saat, Norshahril. 2012. "Islamizing Malayness: Ulama Discourse and Authority in Contemporary Malaysia." Contemporary Islam 6: 135-153.

Turner, Bryan S. 2007. "Religious Authority and the New Media." Theory, Culture, and Society 24(2): 117-134.

Weber, Max. 1957. Theory of Social and Economic Organisations, Translated by Henderson and Talcott Parsons. Glancoe-Ill: The Free Press.

Weng, Hew Wai. 2018. "The Art of Da'wah: Social Media, Visual Persuasion, and the Islamist Propagation of Felix Siauw." Indonesia and the Malay World 134(46): 61-79.

Yunus, M. 2015. Memperkerjakan Anak di Bawah Umur Perspektif Hukum Islam: Studi Kasus di Persimpangan Lampu Merah Sudirman-Tambusai. Pekanbaru: UIN Sultan Syarif Kasim Riau.

Zulkifli. 2013. "The Ulama in Indonesia: Between Religious Authority and Symbolic Power." Miqot 37(1): 180-197. 